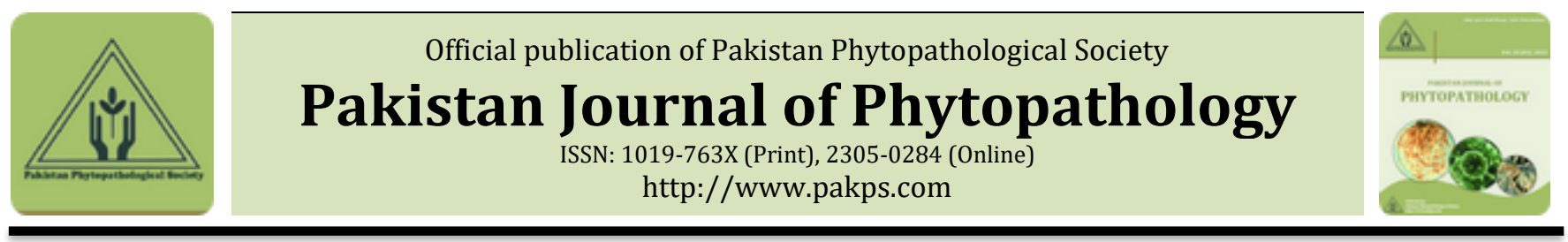

\title{
SINGLE SPORE ISOLATION AND MOLECULAR CHARACTERIZATION OF TRICHODERMA SPECIES FROM AGRICULTURAL FIELDS OF ZHEJIANG PROVINCE, CHINA
}

\author{
aBaharullah Khattak*, ${ }^{b}$ Hong K. Wang, bFucheng Lin, cSaifullah, aQaiser Jamal, dIjaz A. Khan \\ aDepartment of Microbiology, Kohat University of Science and Technology Kohat, Pakistan. \\ ${ }^{b}$ Fungal Biology Lab, Institute of Biotechnology, Zhejiang University, Hangzhou, P.R. China. \\ 'Department of Plant Pathology, the University of Agriculture Peshawar, Pakistan. \\ ${ }^{d}$ Department of Weed Science, the University of Agriculture Peshawar, Pakistan.
}

\begin{abstract}
A B S T R A C T
It is well known that Trichoderma spp. can be used as a biological control agent against variety of plant pathogens. In this study, Trichoderma species were isolated from rhizosphere samples of various sites in Zhejiang province, China. A total of 41 soil samples were processed for the isolation of single cell culture of Trichoderma sp. Out of which, 32 species of the genus Trichoderma, were isolated and characterized by using single spore isolation method. The isolates were subjected to sequencing, for precise identification up to species level. Trichoderma harzianum was isolated from maximum (09) number of soil samples, followed by T. velutinum, isolated from 3 soil samples. The other isolated species of the genus Trichoderma were; lixii, atroviride, koningii, longibrachatum, rossicum, gamsii, koningiopsis, tomentosum, afroharzianum, viride, citroviride, aureoviride, simmonsii and hamatum. It was concluded that Trichoderma sp. were abundantly found in the agricultural soils of Zhejiang province, China.
\end{abstract}

Keywords: Trichoderma, Biocontrol, Fungi, Rhizoshphere, single spore culture

\section{INTRODUCTION}

Trichoderma is a common filamentous imperfect fungus that belongs to class Deuteromycetes, and family Dematiaceae. It is a common saprophytic fungus in the rhizosphere and found in almost any soil. Trichoderma species are cosmopolitan fungi, frequently present in all types of soils (Alexander, 1961). Trichoderma spp. are free living fungi that are common in soil and root ecosystems and promote plant growth (Yedidia et al., 2001). The importance of this genus is evident from its biocontrol potential against several soil borne plant pathogens (Papavizas 1985; Elad et al. 1993; Elad 2000; Freeman et al. 2004; Dubey et al. 2007; Windham et al. 1989; Sharon et al. 2001). The growth of plants with Trichoderma spp. alone or in combination with

\author{
Submitted: August 09, 2018 \\ Revised: September 15, 2018 \\ Accepted for Publication: November 22, 2018 \\ * Corresponding Author: \\ Email: baharkk75@gmail.com \\ (C) 2017 Pak. J. Phytopathol. All rights reserved.
}

pathogen was greater than in plants inoculated with pathogen alone (Sreedevi et al., 2011). Trichoderma has recently been reported as an effective entomopathogenic fungus against Bemisia tabaci (Waheed et al., 2016)

The process of fungal identification does not rely solely on morphological features for identification. The use of fungal cultures, obtained from single spore isolations is fundamental to the identification of many fungi. The importance of careful identification of fungi and obtaining cultures that have been isolated from single spores cannot be over stressed (Smith, 1969). Isolation methods must be simple to perform, even for those who do not have experience in isolation, relatively inexpensive and effective. Simple, inexpensive and effective methods have been described to isolate fungi from single spore cultures (Choi et al., 1999). The phylogenetic species concept, which can include comparison of both morphological and molecular characters, in most cases require single spore cultures (Goh and Hanlin, 1997). 
For the storage of fungal pure culture, it can be maintained on an agar slant at $4^{\circ} \mathrm{C}$ or stored as a few pieces of agar with mycelia in cryo vials with $10 \%$ glycerol in liquid nitrogen. Alternatively, it can be stored as a few pieces of agar with mycelia in small bottle with sterilized parafin oil or sterilized water at $4^{\circ} \mathrm{C}$. There are several other methods to maintain fungal cultures and as reviewed in the "Preservation and Maintenance of Living Fungi" (Smith and Onions, 1994).

The present research was mainly focused on the single spore isolation and molecular characterization of Trichoderma sp. from soil of Zhejiang province, China.

\section{MATERIALS AND METHODS}

Soil Sampling: Soil samples were collected from various ecological habitats of cultivated vegetable crops of Zhejiang province, China for the isolation of Trichoderma spp. Samples were stored at $4^{\circ} \mathrm{C}$ until further used.

Isolation of Trichoderma species: For the isolation of single spore Trichoderma strains, a serial dilution technique was followed. Soil suspension was prepared from each sample by adding $1 \mathrm{~g}$ of soil into $100 \mathrm{ml}$ of sterile distilled water, serial dilutions were prepared and $0.5 \mathrm{ml}$ from $10^{-4}$ dilution of each soil suspension was pipetted onto water agar (WA) plates. It was gently spread over WA with a glass spreader and incubated at $28^{\circ} \mathrm{C}$. The culture plates were examined daily and the individual colony was isolated and sub cultured onto fresh Potato Dextrose Agar (PDA) plates. The pure cultures of Trichoderma sp. were stored in 20\% glycerin at $-80^{\circ} \mathrm{C}$ for long time storage.

\section{Molecular Characterization of Trichoderma strains:}

For the molecular characterization of Trichoderma strains, DNA was isolated from the pure culture, amplified through PCR and subjected for sequencing of the amplified product.

Extraction of fungal DNA: Isolation of fungal DNA is a multi-step method. It includes growing the fungus in liquid or solid medium, lyophilizing the fungal samples, disrupting cell wall, removing proteins with phenol and chloroform, and precipitating DNA with ethanol or Isopropanol. In this experiment, DNA from fungal mycelia was isolated by adopting a modified technique, as reported by (Saitoh et al., 2006; Tripathy et al., 2017). Steps involved in DNA extraction were as follows:

- Took 700 ul extraction or lyces buffer (Tris-HCl, EDTA, $150 \mathrm{mM} \mathrm{NaCl}, 1 \%$ SDS, pH 8.0) in $1.5 \mathrm{ml}$ Eppendorf tube.
- A small amount from 10-day old fungal culture was added into the buffer, by using a sterile toothpick.

- Quartz sand was added into the culture and the tubes were subjected to tissue lyses at $65,000 \mathrm{~Hz}$ for $2 \mathrm{~min}$.

- Centrifuge at $12,000 \mathrm{rpm}$ for $10 \mathrm{~min}$.

- Discarded pellet with sand particles and took $650 \mathrm{ul}$ supernatant into tubes.

- Added 650 ul Chloroform (CIA) to the tubes and shake at $150 \mathrm{rpm}$ for $15 \mathrm{~min}$.

- Centrifuge at 12,000 for $10 \mathrm{~min}$.

- Remove 550 ul of the supernatant into new tubes and added $550 \mathrm{ul}$ of Isopropanol left for $30 \mathrm{~min}$.

- Centrifuge at 12,000 for $10 \mathrm{~min}$.

- Discarded the supernatant and collected the pellet.

- Washed DNA pellet twice with 70\% ETOH (500 ul) and air dried.

- Added $50 \mathrm{ul}$ Eluent and left for $10 \mathrm{~min}$ before PCR.

DNA Amplification by PCR: For DNA amplification, first PCR Mix was prepared, which contained 15ul Taq mix, 1 ul Primer-1, 1ul Primer-2, 1ul fungal DNA, 12 ul dd $\mathrm{d}_{2} \mathrm{O}$, making it 30ul volume. The PCR protocol, given by (Lee and Taylor 1990) was used for the fungal DNA amplification. The PCR reactions involved 1 cycle at $95^{\circ} \mathrm{C}$ for $5 \mathrm{~min}$, followed by 34 cycles with a denaturation step at $95^{\circ} \mathrm{C}$ for $30 \mathrm{sec}$, an annealing step at $57^{\circ} \mathrm{C}$ for $30 \mathrm{sec}$, and an extension step at $72^{\circ} \mathrm{C}$ for $1 \mathrm{~min}$, Hold: at $4^{\circ} \mathrm{C}$.

Gel Electrophoresis: After the DNA amplification, the PCR product was subjected for gel electrophoresis. To 25 $\mu \mathrm{l}$ of amplification products obtained after the PCR, $2 \mu \mathrm{l}$ of loading dye (bromophenol blue) were added and loaded into individual wells of $1.0 \%$ Agarose in $1 \times$ TBE buffer. Electrophoresis was carried out at $100 \mathrm{~V}$ for $2 \mathrm{~h}$, and thereafter the gel was stained with ethidium bromide $\left(10 \mathrm{mg} \mathrm{\mu l}^{-1}\right)$.

Put 1\% Agarose gel in a gel tank and Ethedium bromide dye was added into it. A comb was placed gently and allowed the gel to solidify. Removed comb carefully and placed the gel in a gel tank. Loaded 7 ul PCR products into each well and a ladder DNA was loaded to a side. Run the gel at $110 \mathrm{~A}, 400 \mathrm{~V}$ for $20 \mathrm{~min}$. Detection of DNA was made on a trans-illuminator under UV light. The DNA samples with clear bands were sent to the company for sequencing. After getting the sequencing data, a tree was prepared to check the similarity index among the fungal isolates.

Storage of Cultures: The pure culture was maintained on an agar slant at $4^{\circ} \mathrm{C}$ or stored as a few pieces of agar 
with mycelia in cryo vials with $10 \%$ glycerol in liquid nitrogen.

\section{RESULTS AND DISCUSSION}

Biological control of plant pathogens by microorganisms has been considered as a natural and environmentally acceptable alternative to the existing chemical treatment methods (Baker and Paulitz, 1996). Intensified use of fungicides resulted in the accumulation of toxic compounds potentially hazardous to humans and environment (Cook and Baker, 1983).

Trichoderma is an important filamentous fungus, which has recently gained immense importance due to its biological control ability against several plant pathogens, in decomposition of organic wastes, production of enzymes like xylanases, cellulases. In the present study, single spore cultures of Trichoderma isolates were subjected for the molecular identification of different Trichoderma species isolates present in different fields of Zhejiang province, China. Ranga et al., (2017) studied the genetic diversity of Trichoderma sp. from Rhizosphere regions of different cropping systems using RAPD markers. Results show that 32 species of Trichoderma have been isolated from agriculture soil of various vegetable fields in Zhejiang province, China (Table 1). Trichoderma harzianum was isolated from maximum (09) number of soil samples, followed by $T$. velutinum, isolated from 3 soil samples. Trichoderma harzianum has been reported as the most among common, among the biological control agents of the genus Trichoderma (Hermosa et al., 2000). Five Trichoderma species i.e. lixii, atroviride, koningii, longibrachatum and rossicum were isolated from the samples 607, 47, 252, 13 and 561 respectively. The other Trichoderma sp. like gamsii, koningiopsis, tomentosum, afroharzianum, viride, citroviride, aureoviride, simmonsii and hamatum were isolated from the soil samples, designated as 498,505 , $584,10,52,542,51,531$ and 494, respectively as shown in Table 1. The Agarose gel electrophoresis of PCR products of ITS region is shown in Figure 1. A Dendrogram, depicting variation among isolates of Trichoderma spp., is given in Figure 2.

Table 1. List of species of Trichoderma sp., collected from various agricultural fields in Zhejiang province, China

\begin{tabular}{cll}
\hline S.No. & Sample & Trichoderma Species \\
\hline 1 & 498 & Trichoderma gamsii \\
\hline 2 & 505 & Trichoderma koningiopsis \\
\hline 3 & 584 & Trichoderma tomentosum \\
\hline 4 & 406 & Trichoderma harzianum \\
\hline 5 & $33-2$ & Trichoderma velutinum \\
\hline 6 & 607 & Trichoderma lixii \\
\hline 7 & 47 & Trichoderma atroviride \\
\hline 8 & 540 & Trichoderma harzianum \\
\hline 9 & 10 & Trichoderma afroharzianum \\
\hline 10 & 52 & Trichoderma viride \\
\hline 11 & 252 & Trichoderma koningii \\
\hline 12 & $33-1$ & Trichoderma velutinum \\
\hline 13 & 53 & Trichoderma koningii \\
\hline 14 & 13 & Trichoderma longibrachiatum \\
\hline 15 & 542 & Trichoderma citrinoviride \\
\hline 16 & 561 & Trichoderma rossicum \\
\hline 17 & 51 & Trichoderma aureoviride \\
\hline 18 & 531 & Trichoderma simmonsii \\
\hline 19 & 495 & Trichoderma lixii \\
\hline 20 & 17 & Trichoderma harzianum \\
\hline 21 & 33 & Trichoderma harzianum \\
\hline 22 & 37 & Trichoderma harzianum \\
\hline 23 & 637 & Trichoderma harzianum \\
\hline 24 & $33-1$ & Trichoderma velutinum \\
\hline 25 & 492 & Trichoderma harzianum \\
\hline 26 & 494 & Trichoderma hamatum \\
\hline 27 & 36 & Trichoderma longibrachiatum \\
\hline 28 & 35 & Trichoderma harzianum \\
\hline 29 & 6 & Trichoderma atroviride \\
\hline 30 & 353 & Trichoderma harzianum \\
\hline 31 & 26 & Trichoderma rossicum \\
\hline 32 & 541 & Trichoderma stromaticum \\
\hline & & \\
\hline
\end{tabular}

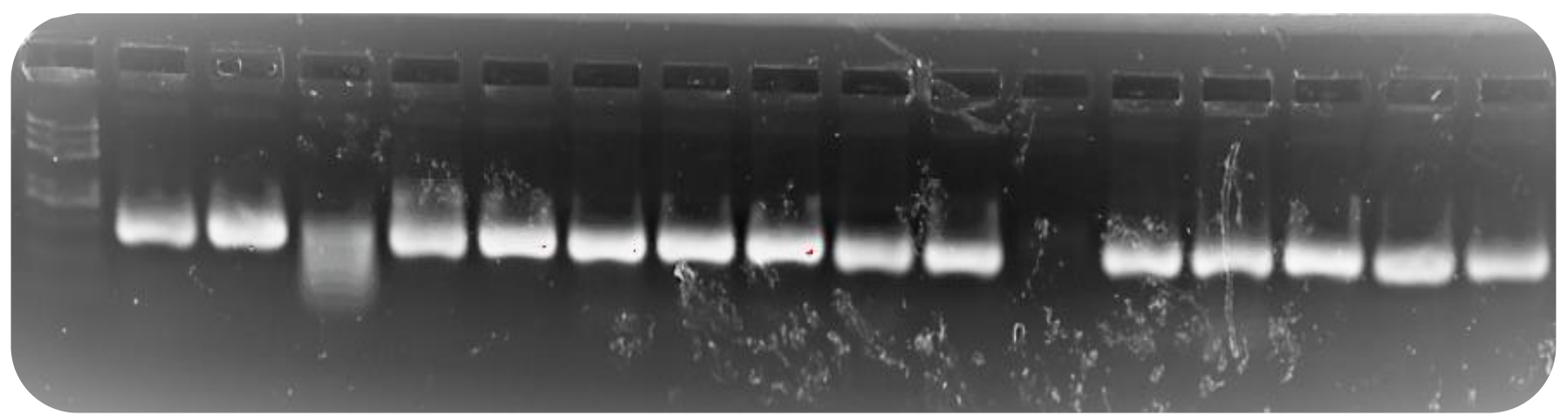

Figure 1. Agarose gel electrophoresis of PCR products of ITS region. 


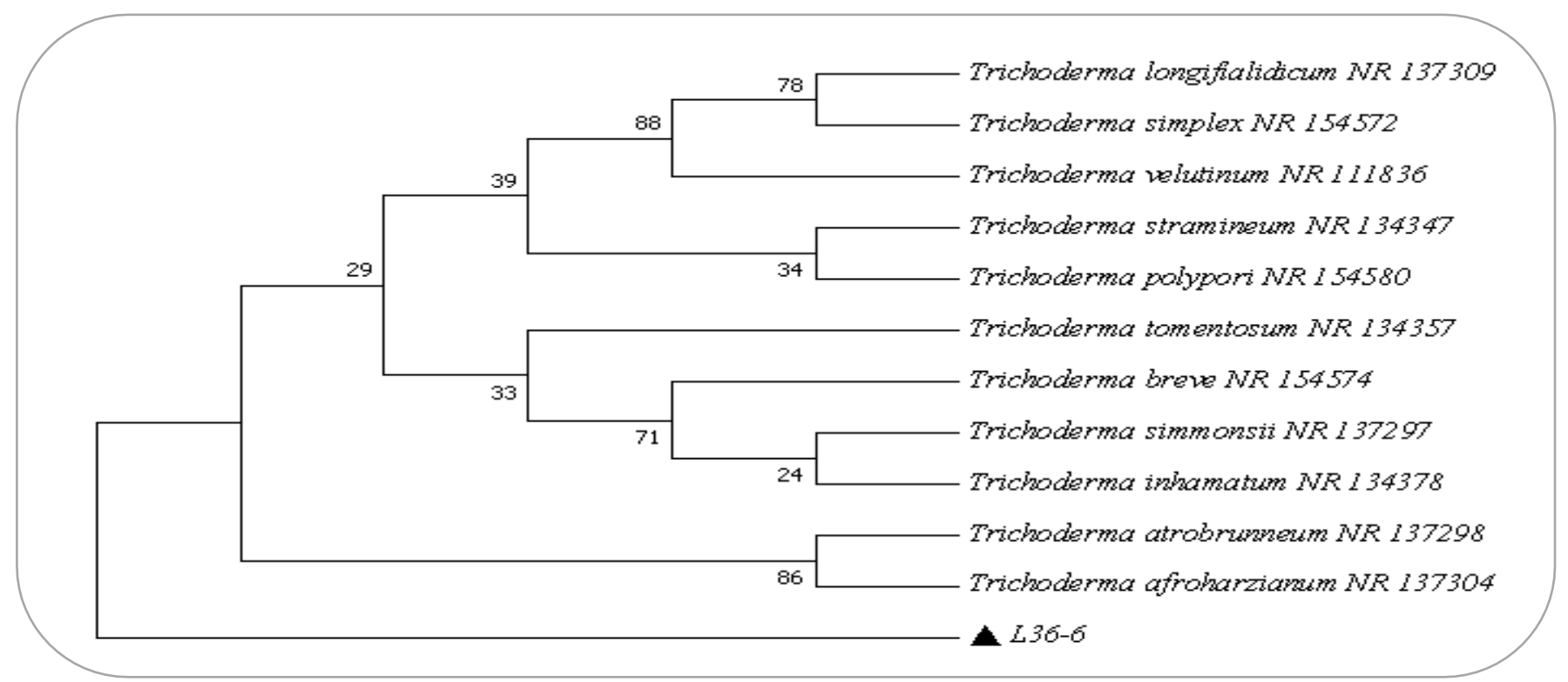

Figure 2. Dendrogram, depicting variation among isolates of Trichoderma spp.

\section{CONCLUSION AND RECOMMENDATIONS}

Single spore cultures of Trichoderma isolates were subjected for the molecular characterization of Trichoderma sp., collected from the agriculture fields of Zhejiang province, China. Out of the 32 isolated species of Trichoderma, 9 were reported as T. harzianum, 3 were T. velutinum. The biocontrol potential of these isolates of Trichoderma against various pathogens needs to be investigated.

\section{ACKNOWLEDGEMENTS}

The authors express thanks to the Higher Education Commission for the financial support under the Pakistan Program for Collaborative Research (PPCR). We would like to thank Institute of Biotechnology, Zhejiang University, P.R China, for providing research facilities and extending technical and administrative support.

\section{REFERENCE}

Alexander, M. 1961. Introduction to soil microbiology. In. Wiley J \& Sons., New York and London.

Baker, R. and T. Paulitz. 1996. Theoretical basis for microbial interactions leading to biological control of soil borne plant pathogens. Principles and Practice of Managing Soilborne Plant Pathogens. R. Hall, ed. American Phytopathological Society, St. Paul, MN: 50-79.

Choi, Y.W., K.D. Hyde and W. Ho. 1999. Single spore isolation of fungi. Fungal diversity.

Cook, R.J. and K.F. Baker. 1983. The nature and practice of biological control of plant pathogens. American Phytopathological Society.
Dubey, S.C., M. Suresh and B. Singh. 2007. Evaluation of Trichoderma species against Fusarium oxysporum f. sp. ciceris for integrated management of chickpea wilt. Biological Control, 40: 118-127.

Elad, Y., 2000. Biological control of foliar pathogens by means of Trichoderma harzianum and potential modes of action. Crop Protection, 19: 709-714.

Elad, Y., G. Zimand, Y. Zaqs, S. Zuriel and I. Chet. 1993. Use of Trichoderma harzianum in combination or alternation with fungicides to control cucumber grey mould (Botrytis cinerea) under commercial greenhouse conditions. Plant Pathology, 42: 324332.

Freeman, S., D. Minz, I. Kolesnik, O. Barbul, A. Zveibil, M. Maymon, Y. Nitzani, B. Kirshner, D. Rav-David, A. Bilu, A. Dag, S. Shafir and Y. Elad. 2004. Trichoderma Biocontrol of Colletotrichum acutatum and Botrytis cinerea and Survival in Strawberry. European Journal of Plant Pathology, 110: 361-370.

Goh, T.K. and R.T. Hanlin. 1997. Nuclear divisions in the ascus and ascospores of Melanospora zamiae. Mycological Research, 101: 1511-1514.

Hermosa, M.R., I. Grondona, E.A. Iturriaga, J.M. DiazMinguez, C. Castro, E. Monte and I. Garcia-Acha. 2000. Molecular Characterization and Identification of Biocontrol Isolates of Trichoderma spp. Applied and Environmental Microbiology, 66: 1890-1898.

Lee, S. B. and J. W. Taylor. 1990. Isolation of DNA from 
fungal mycelia and single spores. PCR Protocols. Elsevier, pp. 282-287.

Papavizas, G. 1985. Trichoderma and Gliocladium: Biology, Ecology, and Potential for Biocontrol. Annual Review of Phytopathology, 23: 23-54.

Ranga, A. R., S. A. Khayum and A. K. Patibanda. 2017. Genetic Diversity of Trichoderma sp. from Rhizosphere Regions of Different Cropping Systems using RAPD Markers. International Journal of Current Microbiology and Applied Sciences, 6: 1618-1624.

Saitoh, K.I., K. Togashi, T. Arie and T. Teraoka. 2006. A simple method for a mini-preparation of fungal DNA. Journal of General Plant Pathology, 72: 348350.

Sharon, E., M. Bar-Eyal, I. Chet, A. Herrera-Estrella, 0. Kleifeld and Y. Spiegel. 2001. Biological Control of the Root-Knot Nematode Meloidogyne javanica by Trichoderma harzianum. Phytopathology, 91: 687693.

Smith, G. 1969. An Introduction to Industrial Mycology. 6. Aufl. 380 Seiten 2 Tab., 172 Fig. Edward Arnold (Publishers) Ltd., London, Preis: 80 s. Food / Nahrung, 15: 465-465.

Smith, O. and A. H. S. Onions. 1994. The preservation and maintenance of living fungi, 2nd edition.
Veterinary Dermatology, CAB International, UK. 5: 215-215.

Sreedevi, B., M. Charitha Devi and D. Saigopal. 2011. Isolation and screening of effective Trichoderma spp. against the root rot pathogen Macrophomina phaseolina. Journal of Agricultural Technology, 7: 623-635.

Tripathy, S.K., M. Maharana, D.M. Ithape, D. Lenka, D. Mishra, A. Prusti, D.S. Ranjan Mohanty and K.R.R. Raj. 2017. Exploring Rapid and Efficient Protocol for Isolation of Fungal DNA. International Journal of Current Microbiology and Applied Sciences, 6: 951-960.

Waheed, A., M.N. Subhani, M.S. Haider, A.A. Shahid, H. Mushatq, M. Z. Rehman, U. Hameed and S. Javed. 2016. First record of Trichoderma longibrachiatum as entomopathogenic fungi against Bemisia tabaci in Pakistan. Pakistan Journal of Phytopathology, 28: 287-294.

Windham, G.L. 1989. Effects of Trichoderma spp. on Maize Growth and Meloidogyne arenaria Reproduction. Plant Disease, 73: 493.

Yedidia, I., A.K. Srivastva, Y. Kapulnik and I. Chet. 2001. Effect of Trichoderma harzianum on microelement concentrations and increased growth of cucumber plants. Plant and Soil, 235: 235-242. 